\title{
Sintesis Zeolit A Dari Coal Bottom Ash Dengan Metode Step Change Of Synthesis Temperature Dengan Variasi Suhu Kalsinasi Diaplikasikan Untuk Dehidrasi Etanol
}

\author{
Simparmin Br. Ginting. ${ }^{1}$, M. Yassien Nurfiqih ${ }^{1}$ \\ ${ }^{1}$ Program Studi Teknik Kimia, Fakultas Teknik Universitas Lampung \\ email : simparmin.ginting@eng.unila.ac.id
}

\begin{abstract}
Abstrak
Telah dilakukan penelitian mengenai pembuatan zeolit A yang diaplikasikan untuk dehidrasi etanol dengan menggunakan metode step change of synthesis temperature dengan temperatur awal $90^{\circ} \mathrm{C}$ selama 1,5 jam kemudian dinaikkan menjadi $95^{\circ} \mathrm{C}$ selama 2,5 jam. Bahan baku yang digunakan adalah coal bottom ash PLTU Tarahan Lampung Selatan, yang dikalsinasi pada suhu yang bervariasi yaitu $500^{\circ} \mathrm{C}, 600^{\circ} \mathrm{C}, 700^{\circ} \mathrm{C}$ dan $800^{\circ} \mathrm{C}$. Tahapan yang dilakukan adalah kalsinasi, sintesis dan adsorpsi. Penelitian ini bertujuan untuk mendapatkan zeolit A sintetis dari variasi suhu kalsinasi agar didapatkan persen kristalinitas yang tinggi yang diharapkan dapat menjerap air dalam campuran etanol dengan optimal, sehingga etanol memiliki kemurnian $>99 \%$ (Fuel Grade Ethanol). Karaktersiasi zeolit A sintetis menggunakan difraktometer sinar-x (XRD), spektrometer inframerah (FTIR), scanning electron microscope (SEM) dan brunnaur, emmet dan teller (BET). Berdasarkan analisis XRD didapatkan persen kristalinitas tertinggi pada variasi suhu kalsinasi $500^{\circ} \mathrm{C}$ yaitu sebesar $34,79 \%$, hasil analisis FTIR menunjukkan telah terbentuk produk Zeolit A yang ditandai dengan adanya karakteristik Zeolit A pada bilangan gelombang $950-1250 \mathrm{~cm}^{-1}, 650-750 \mathrm{~cm}^{-1}, 500-650 \mathrm{~cm}^{-1}, 420-500 \mathrm{~cm}^{-1}$ dan $300-400 \mathrm{~cm}^{-1}$, hasil analisis SEM menunjukkan semua variasi suhu kalsinasi terlihat bahwa bentuk partikel didominasi bentuk kubus, berdasarkan analisis BET diketahui Zeolit A berukuran mesopori yang memiliki kisaran diameter 2-50 nm. Dari hasil uji adsorspsi etanol-air diperoleh kemurnian etanol akhir tertinggi pada variasi suhu kalsinasi $500^{\circ} \mathrm{C}$ yaitu sebesar 99,202\%.
\end{abstract}

Kata kunci : coal bottom ash, kalsinasi, kristalinitas, metode Step Change Temperature, zeolit A.

\section{PENDAHULUAN}

Telah banyak peneletian mengenai pembuatan bioetanol sebagai langkah untuk mengantisipasi kelangkaan bahan bakar minyak pada kendaraan bermotor. Namun penggunaan bioetanol sebagai pengganti bahan bakar bermotor memiliki kendala yaitu masih mengandung 4-5\% air yang dapat mengganggu kinerja mesin dan dapat mengakibatkan kerusakan pada mesin jika digunakan dalam jangka waktu yang lama, sehingga diperlukan pengolahan lebih lanjut [1]. Jika bioetanol ingin digunakan sebagai bahan bakar (biofuel) pada kendaraan bermotor perlu dimurnikan sampai $99-100 \%$ yang lazim disebut fuel grade ethanol (FGE) [2]. Cara pemurnian paling sederhana dan relatif lebih murah untuk diterapkan pada unit pemurnian bietanol adalah teknik dehidrasi dengan cara penyaringan molekuler menggunakan zeolit atau disebut juga zeolit molecular sieve [3].

Salah satu bahan dasar untuk pembuatan zeolit adalah coal bottom ash hasil pembakaran batubara pada Pembangkit Listrik Tenaga Uap (PLTU). Coal bottom ash tergolong sebagai limbah B3 (Bahan beracun dan berbahaya) menurut peraturan pemerintah No. 18 tahun 1999. Oleh karena itu perlu dilakukan penanganan khusus untuk mengurangi limbah coal bottom ash serta menjadikannya material yang memiliki manfaat dalam bidang tertentu, dalam hal ini pemurnian bioetanol. Salah satu contoh limbah coal bottom ash yaitu terdapat pada Pembangkit Listrik Tenaga Uap (PLTU) Tarahan, Lampung Selatan yang mengandung silikon dioksida $\left(\mathrm{SiO}_{2}\right) \quad 77,76 \%$, aluminium oksida $\left(\mathrm{Al}_{2} \mathrm{O}_{3}\right) \quad 16,53 \%$, besi oksida $\left(\mathrm{Fe}_{2} \mathrm{O}_{3}\right) 1,004 \%$, kalsium oksida $(\mathrm{CaO}) 1,854 \%$ dan sisanya senyawa-senyawa lain dalam jumlah kecil. (Hasil analisis XRF coal bottom ash PLTU Tarahan, 2015). Unsur kimia Si dan Al ditemukan dalam fasa amorf maupun fasa kristalin. Unsur unsur kimia tersebut merupakan komponen penyusun zeolit sehingga dengan proses tertentu coal bottom ash dapat diubah menjadi zeolit [4].

Proses sintesis zeolit A masih mengacu pada metode yang digunakan oleh Richard Barrer melalui metode hidrotermal [5]. Sebagian besar peneliti melakukan sintesis zeolit A pada temperatur di bawah $100^{\circ} \mathrm{C}$ seperti yang dilakukan oleh Leonard (1981), Sun (1983), Vaughan (1985), Kuznicki et al. (2002), dan Diaz et al. (2010) [3]. Pada penelitian ini digunakan metode sintesis hidrotermal dengan menggunakan metode step change temperature, dimana pada metode ini terjadi dalam dua tahap sintesis, sintesis yang pertama menggunakan suhu $90^{\circ} \mathrm{C}$ selama 1,5 jam kemudian suhu dinaikkan menjadi $95^{\circ} \mathrm{C}$ selama 2,5 
jam. Tahap pertama proses sintesis sangat efektif dalam proses nukleasi, sedangkan pada tahap kedua dimaksudkan untuk pembentukan kristal zeolit A yang optimal [6].

Salah satu perlakuan awal coal bottom ash adalah kalsinasi. Telah dilakukan sintesis zeolit dengan menggunakan kaolin, dikatakan bahwa pembentukan zeolit A terbaik pada suhu kalsinasi $600{ }^{\circ} \mathrm{C}$ selama satu jam dengan suhu reaksi $100{ }^{\circ} \mathrm{C}$ [12]. Juga telah melakukan sintesis zeolit A dengan menggunakan kaolin, dikatakan kondisi sintesis terbaik zeolit A terjadi pada suhu kalsinasi $700{ }^{\circ} \mathrm{C}$ dengan temperatur reaksi $100{ }^{\circ} \mathrm{C}$ [8]. Telah diamati pembentukan zeolit A dari kaolin yang dikalsinasi pada suhu $800{ }^{\circ} \mathrm{C}$ dengan $\mathrm{NaOH}$ konsentrasi $4 \mathrm{M}$ pada temperatur reaksi $70-100{ }^{\circ} \mathrm{C}$, dikatakan pembentukan zeolit A dapat dipengaruhi oleh kalsinasi starting material [19].

Berdasarkan penelitian terdahulu yang telah dilakukan, terlihat bahwa terdapat perbedaan dalam kondisi suhu kalsinasi yang digunakan, namun tetap menghasilkan zeolit A. Oleh karena itu pada penelitian ini akan dikaji pengaruh suhu kalsinasi dengan menggunakan coal bottom ash hasil pembakarn batubara PLTU Tarahan dengan menerapkan metode step change of synthesis temperature untuk memperoleh zeolit A dengan persen kristalinitas yang tinggi sehingga dapat digunakan sebagai adsorben dalam dehidrasi etanol-air.

\section{METODOLOGI PENELITIAN}

Penelitian ini bertujuan untuk mengetahui pengaruh suhu kalsinasi dengan mengunakan metode step change of synthesis temperature dimana suhu sintesis yang pertama yaitu $90^{\circ} \mathrm{C}$ kemudian dinaikkan menjadi $95^{\circ} \mathrm{C}$. Langkah penelitian yang dilakukan yaitu kalsinasi coal bottom ash, pembuatan gel silika alumina, proses sintesis zeolit A, dan karakterisasi zeolit dengan XRD, FTIR, SEM, dan BET.

Alat yang digunakan dalam penelitin ini yaitu mortar, ayakan mesh, furnace, erlenmeyer, corong gelas, neraca digital, botol polypropylene, water bath, $\mathrm{pH}$ indikator, desikator, kertas saring dan oven. Sedangkan bahan yang digunakan dalam penelitian ini yaitu coal bottom ash dari PLTU Tarahan, Lampung Selatan dengan kandungan $\mathrm{SiO}_{2}$ sebesar 77,76\% dan $\mathrm{Al}_{2} \mathrm{O}_{3}$ sebesar 16,53\%, padatan $\mathrm{NaOH}$ (pro analysis dari UNI-CHEM, kadar 96\%), serbuk $\mathrm{Al}_{2} \mathrm{O}_{3}$ sebagai sumber alumina (pro analysis dari UNI-CHEM, kadar 99\%), dan aquades didapatkan dari Laoratorium Terpadu, Fakultas Pertanian, Universitas Lampung.
Prosedur penelitian terdiri dari pretreatment bahan baku, pembuatan larutan silika alumina dan proses sintesis

\section{Pretreatmen bahan baku}

coal bottom ash sebanyal 11,711 gram dihaluskan menggunakan mortal setelah itu diayak menggunakan ayakan mesh (200 mesh) kemudian di kalsinasi didalam furnace dengan variasi kalsinasi 500, 600, 700 dan $800{ }^{\circ} \mathrm{C}$ selama satu jam.

2. Pembuatan larutan silika alumina mengacu pada hasil penelitian $M$. Mirfendereski dan $T$. Mohammadi, (2016) [7]. dengan komposisi molar gel silika alumina $=1,92 \mathrm{SiO}_{2}: \mathrm{Al}_{2} \mathrm{O}_{3}$ : $3,16 \mathrm{Na}_{2} \mathrm{O}: 128 \mathrm{H}_{2} \mathrm{O}$. Tahapan pembuatannya sebagai berikut :

a. Pembuatan larutan sodium hidroksida Larutkan $\mathrm{NaOH}$ sebanyak 10 gram kedalam 182,269 $\mathrm{mL}$ akuades Kemudian larutan $\mathrm{NaOH}$ dibagi menjadi 2 bagian dengan jumlah volume yang sama.

b. Pembuatan larutan sodium silikat

Larutkan 11,711 gram coal bottom ash kedalam salah satu larutan sodium hidroksida dan diaduk hingga homogen pada suhu $60 \quad{ }^{\circ} \mathrm{C}$ selama satu jam menggunakan magnetic stirrer.

c. Pembuatan larutan sodium aluminat

Larutkan 6,133 gram $\mathrm{Al}_{2} \mathrm{O}_{3}$ kedalam salah satu larutan sodium hidroksida dan diaduk hingga homogen pada suhu $60{ }^{\circ} \mathrm{C}$ selama satu jam menggunakan magnetic stirrer.

d. Pembuatan larutan silika alumina

Campurkan larutan sodium silikat dengan larutan sodium hidroksida dan diaduk hingga homogen pada suhu $60{ }^{\circ} \mathrm{C}$ selama satu jam menggunakan magnetic stirrer.

3. Tahap sintesis

Tahapan sintesisi mengacu pada hasil penelitian Hui K.S dan Chao C.Y.H, 2005 [6]. Larutan silika alumina dimasukkan ke dalam botol polypropylene (PP) dan direaksikan secara hidrotermal pada water bath. Proses sintesis menggunakan metode step change, sintesis yang pertama menggunakan suhu $90^{\circ} \mathrm{C}$ selama 1,5 jam kemudian suhu dinaikkan menjadi $95^{\circ} \mathrm{C}$ selama 2,5 jam.

Setelah tahap sintesis, sampel disaring menggunakan kertas saring untuk memisahkan padatan dengan mother liquor (filtrat). Padatan yang merupakan produk dari sintesis dicuci beberapa kali menggunakan akuades sampai didapatkan nilai $\mathrm{pH} \quad 7$ kemudian padatan dikeringkan didalam oven dengan suhu $100{ }^{\circ} \mathrm{C}$ selama dua jam. Padatan yang sudah kering 
disimpan didalam desikator sebelum dilakukan analisis. Analisis yang dlakukan berupa XRD, FTIR, SEM, dan BET.

\section{HASIL DAN PEMBAHASAN}

\section{X-Ray Diffraction (XRD)}

Analisis dengan XRD dilakukan untuk mengetahui struktrur kristal, baik dalam fasa amorf maupun kristal serta komposisi mineral-mineral penyusunnya. Karakterisasi XRD ini menggunakan radiasi $\mathrm{Cu} \mathrm{K \alpha}$, dengan tegangan $40 \mathrm{Kv}$, arus 30 $\mathrm{mA}$, dan rentang sudut $2 \theta=5-70^{\circ}$, yang dilakukan di Laboratorium Fisika Terpadu Universitas Negeri Padang (UNP). Analisis XRD dilakukan pada sampel coal bottom ash sebelum kalsinasi, setelah kalsinasi dan setelah proses sintesis. Kemudaian dihitung nilai persen kristalinitas, berdasarkan jurnfal Estimation Of Crystallinity In FAZ-A Using XRD And IR Spectroscopy [11].

Hasil analisis XRD coal bottom ash sebelum kalsinasi menunjukkan persen kristalinitas quartz sebesar $131,89 \%$. Hal ini menandakan bahwasanya coal bottom ash memiliki fasa kristal yang kuat, sehingga perlu dilakukan peluruhan kristal quartz agar mempermudah proses pembentukan kristal yang baru. Peluruhan kristal quartz dilakukan dengan cara kalsinasi, persen kristalinitas quartz coal bottom ash setelah kalsinasi 500, 600, 700 dan $800^{\circ} \mathrm{C}$ ditunjukkan pada Tabel 1.

Tabel 1. Persen Kristalinitas Quartz

\begin{tabular}{cc}
\hline Suhu Kalsinasi & Kristalinitas (\%) \\
\hline $500^{\circ} \mathrm{C}$ & $102,154 \%$ \\
$600^{\circ} \mathrm{C}$ & $106,575 \%$ \\
$700^{\circ} \mathrm{C}$ & $104,748 \%$ \\
$800^{\circ} \mathrm{C}$ & $104,482 \%$ \\
\hline
\end{tabular}

Berdasarkan Tabel 1. dapat dilihat bahwa nilai kristalinitas quartz pada coal bottom ash masih cukup tinggi yaitu berkisar antara 102 $104 \%$, dan juga menunjukkan bahwa variasi suhu kalsinasi coal bottom ash 500, 600, 700 dan $800^{\circ} \mathrm{C}$ tidak memberikan pengaruh yang signifikan terhadap nilia persen kristalinitas quartz. Kemudian hasil karakterisasi XRD setelah proses sintesis ditunjukkan pada Gambar 1.

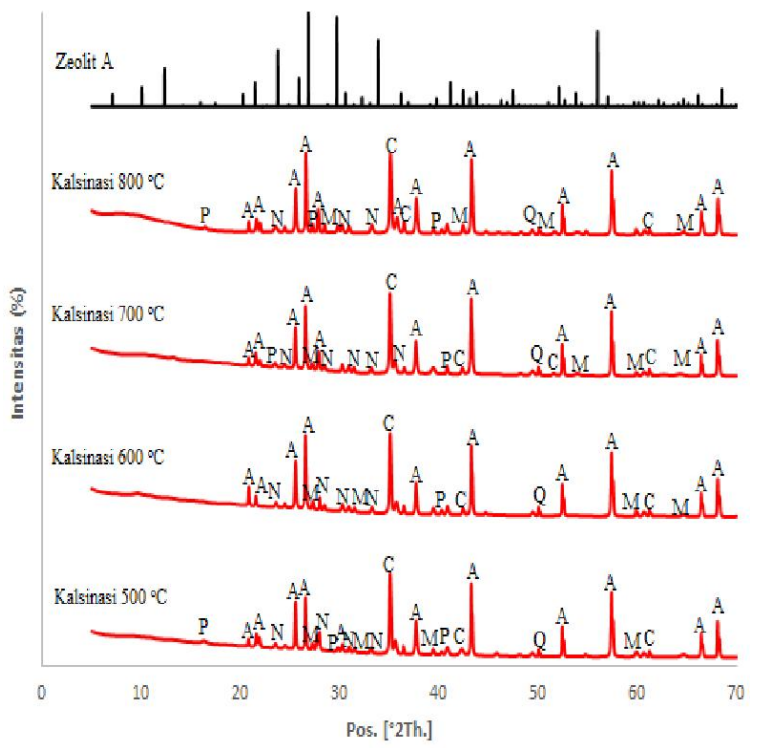

Gambar 1. Hasil XRD Zeolit A Kalsinasi 500, 600, 700 dan $800^{\circ} \mathrm{C}$ dibandingkan dengan zeolit A standar [9]

Keterangan Gambar :

$\mathrm{A}=$ Zeolit $\mathrm{A}\left(\mathrm{Al}_{12} \mathrm{Na}_{12} \mathrm{O}_{48} \mathrm{Si}_{12}\right)$

$\mathrm{M}=$ Mullite $\left(\mathrm{Al}_{2,34} \mathrm{O}_{4,83} \mathrm{Si}_{0,66}\right)$

$\mathrm{C}=$ Corondum $\left(\mathrm{Al}_{2} \mathrm{O}_{3}\right)$

$\mathrm{Ca}=$ Potassium Aluminum Silicate

$$
\left(\mathrm{Al}_{14,52} \mathrm{~K}_{14,52} \mathrm{O}_{48} \mathrm{Si}_{9,48}\right)
$$

$\mathrm{N}=$ Anorthite $\left(\mathrm{Al}_{2} \mathrm{CaO}_{8} \mathrm{Si}_{2}\right)$

$\mathrm{Q}=$ Quartz $\left(\mathrm{SiO}_{2}\right)$

Dari hasil karakterisasi XRD setelah proses sintesis untuk keempat produk zeolit A secara umum dapat terlihat bahwa pada produk sintesis menunjukkan adanya puncak spesifik dari zeolit A standar pada sudut $2 \theta=25,5^{\circ} ; 35^{\circ} ; 37^{\circ} ; 43^{\circ} ; 52^{\circ}$; $57^{\circ} ; 66^{\circ}$ dan $68^{\circ}$ Puncak-puncak ini sesuai dengan puncak-puncak zeolit A [9]. Hal ini menunjukkan bahwa variasi suhu kalsinasi coal bottom ash 500 ${ }^{0} \mathrm{C}, 600{ }^{0} \mathrm{C}, 700{ }^{0} \mathrm{C}$ dan $800{ }^{0} \mathrm{C}$ berhasil disintesis menjadi zeolit $\mathrm{A}$.

Dapat dilihat pada Gambar 1. Selain terbentuk zeolit A, ditemukan juga puncak-puncak lain seperti corrondum, anorthite dan mullite yang ditunjukkan dengan intensitas tajam pada daerah $2 \theta$ $=23,785^{\circ} ; 28,621^{\circ} ; 31,013^{\circ} ; 33,483^{\circ} ; 35,173^{\circ}$; $36,629^{\circ} ; 42,069^{\circ} ; 61,485^{\circ}$ dan $64,943^{\circ}$. Produk samping ini dapat terbentuk karena pengaruh sumber silika, konsentrasi $\mathrm{NaOH}$ dan temperatur [10]. Selanjutnya nilai persen kristalinitas produk ditampilkan pada Tabel 2. 
Tabel 2. Persen Kristalinitas Zeolit A

\begin{tabular}{cc}
\hline Suhu Kalsinasi & Kristalinitas (\%) \\
\hline $500^{\circ} \mathrm{C}$ & $34.79 \%$ \\
$600^{\circ} \mathrm{C}$ & $32.42 \%$ \\
$700^{\circ} \mathrm{C}$ & $33.48 \%$ \\
$800^{\circ} \mathrm{C}$ & $33.95 \%$ \\
\hline
\end{tabular}

Berdasarkan Tabel 2. dapat dilihat bahwa persen kristalinitas zeolit A sintesis yang dihasilkan sangat rendah, yaitu berkisar antara $32-34 \%$. Dapat disimpulkan bahwa perlakuan suhu kalsinasi coal bottom ash tidak memberikan pengaruh yang signifikan terhadap kristalinitas produk. Namun demikian variasi suhu kalsinasi $500^{\circ} \mathrm{C}$ memiliki nilai kristalinitas produk yang paling tinggi, hal ini dikarenakan variasi suhu kalsinasi $500^{\circ} \mathrm{C}$ memilik fasa kristal quartz yang paling sedikit dari variasi suhu kalsinasi yang lain yang dapat dilihat pada Tabel 1. Nilai kristalinitas quartz yang rendah menunjukkan fasa amorf yang terbentuk nilainya tinggi yang menyebabkan zeolit A yang terbentuk nilai kristalinitasnya juga tinggi [12].

Pada Tabel 1. dapat dilihat bahwa variasi suhu kalsinasi $500^{\circ} \mathrm{C}$ memiliki nilai kristalinitas quartz yang paling rendah yang menjadikan fasanya paling amorf dari variasi suhu kalsinasi 600,700 dan $800^{\circ} \mathrm{C}$ sehingga menyebabkan nilai kristalintasnya paling besar. Hal yang serupa juga terdapat pada variasi suhu kalsinasi 600,700 dan $800{ }^{0} \mathrm{C}$. Pada tabel 1. semakin besar nilai kristalintias quartz maka akan menjadikan kristalinitas produk yang terbentuk semakin kecil yang dapat dilihat pada Tabel 2. Hal ini dikarenakan fasa kristal quartz yang masih ada pada coal bottom ash akan sulit diubah menjadi kristal yang lain dikarenakan fasa kristal lebih kokoh dibandingkan fasa amorf. Sehingga fasa amorf sangat diinginkan setelah proses kalsinasi [12]. Berdasarkan hal tersebut, dapat disimpulkan bahwa kenaikan suhu kalsinasi tidak selalu meningkatkan persen kristalinitas produk. Ada suhu optimum melakukan kalsinasi dalam sintesis zeolit A. dimana pada penelitian ini suhu optimumnya adalah $500{ }^{\circ} \mathrm{C}$.

\section{Fourier Transmission Infra Red (FTIR)}

Produk zeolit A hasil sintesis dikarakterisasi dengan FTIR (Fourier Transform InfraRed) Perkin Elmer yang dilakukan di Laboratorium Kimia Instrumen Fakultas MIPA, Universitas Negeri Padang dan spektrum gelombangnya dari 300-2000 $\mathrm{cm}^{-1}$. Analisi FTIR digunakan untuk menentukan ikatan antar atom dan mengetahui gugus fungsi pada sampel [11]. Hasil Karakterisasi FTIR dapat dilihat pada Gambar 2.

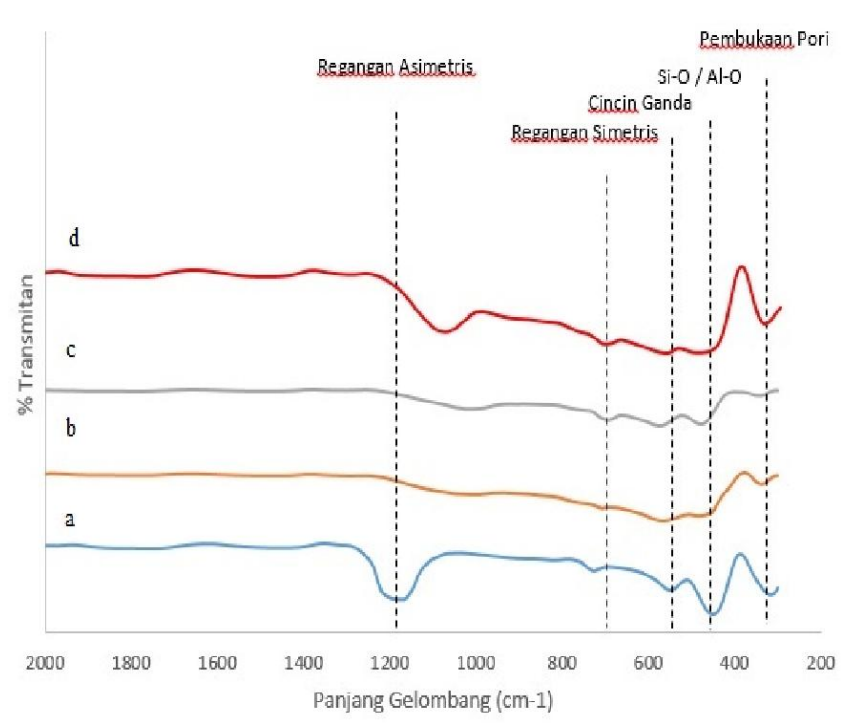

Gambar 2. FTIR Zeolit A Kalsinasi (a) $500^{\circ} \mathrm{C}$, (b) $600^{\circ} \mathrm{C}$, (c) $700^{\circ} \mathrm{C}$ dan (d) $800^{\circ} \mathrm{C}$

Perbandingan bilangan gelombang pada zeolit A standar [13] dan zeolit A sintesis variasi suhu kalsinasi 500, 600, 700 dan $800{ }^{\circ} \mathrm{C}$ disajikan pada Tabel 3.

Tabel 3. Karakteristik FTIR Zeolit A Sintesis

\begin{tabular}{|c|c|c|c|c|}
\hline $\begin{array}{c}\text { Karakteristik } \\
\text { dan Bilangan } \\
\text { Gelombang (cm } \\
\text { 1) Zeolit A } \\
\text { (Hamdan, 1992) }\end{array}$ & $\begin{array}{c}\text { Kalsi } \\
\text { nasi } \\
500 \\
{ }^{\circ} \mathrm{C}\end{array}$ & $\begin{array}{c}\text { Kalsi } \\
\text { nasi } \\
600 \\
{ }^{\circ} \mathrm{C}\end{array}$ & $\begin{array}{c}\text { Kalsi } \\
\text { nasi } \\
700 \\
{ }^{\circ} \mathrm{C}\end{array}$ & $\begin{array}{c}\text { Kalsi } \\
\text { nasi } \\
800 \\
{ }^{\circ} \mathrm{C}\end{array}$ \\
\hline $\begin{array}{c}\text { Regangan } \\
\text { Asimetris } \\
(950-1250)\end{array}$ & 1171 & 1067 & 1000 & 1073 \\
\hline $\begin{array}{l}\text { Regangan } \\
\text { Simetris } \\
(650-750)\end{array}$ & 720 & 697 & 696 & 704 \\
\hline $\begin{array}{l}\text { Vibrasi Cincin } \\
\text { Ganda } \\
(500-650)\end{array}$ & 549 & 564 & 582 & 560 \\
\hline $\begin{array}{c}\text { Vibrasi tekuk } \\
\text { ikatan Si-O/Al- } \\
\text { O } \\
(420-500)\end{array}$ & 451 & 464 & 481 & 479 \\
\hline $\begin{array}{c}\text { Pembukaan Pori } \\
(300-400)\end{array}$ & 317 & 345 & 333 & 335 \\
\hline
\end{tabular}

Pita absorpsi pada bilangan gelombang antara 950-1250 $\mathrm{cm}^{-1}$ menunjukkan bahwa adanya struktur internal tetrahedral O-T-O yang disebabkan vibrasi regangan asimetris pada sampel [14]. Selanjutnya 
puncak pada bilangan gelombang 420-500 $\mathrm{cm}^{-1}$ merupakan vibrasi tekuk ikatan Si-O/Al-O yang menunjukkan bahwa telah terbentuknya cincin $4 \mathrm{R}$ dan 6R akibat dari tekukan antara ikatan T-O-T [13]. Selain itu, terdapat puncak lain yang menunjukkan karakteristik zeolit A yaitu puncak pada bilangan gelombang $500-650 \mathrm{~cm}^{-1}$ yang merupakan rentang vibrasi cincin ganda yang menunjukkan bahwa telah terbentuknya cages yang merupakan Secondary Building Unit dari zeolit A [13]. Vibrasi eksternal dari cincin ganda D4R atau D6R merupakan vibrasi yang menjadi ciri khas terbentuknya struktur zeolit A [15]. Terakhir, pita absorpsi pada bilangan gelombang antara $300-400$ $\mathrm{cm}^{-1}$ menunjukkan bahwa terjadinya pembukaan pori pada susunan cages yang terbentuk [13].

Tabel 3. menunjukkan spectra IR dari sampel sintesis zeolit A (a) $500{ }^{\circ} \mathrm{C}$, (b) $600{ }^{\circ} \mathrm{C}$, (c) $700{ }^{\circ} \mathrm{C}$ dan (d) $800^{\circ} \mathrm{C}$ yang memperlihatkan pita absorpsi yang serupa dengan zeolit A standar. Hal ini menunjukkan bahwa pada semua sampel tersebut terbentuk kristal zeolit A.

\section{Scanning Electron Microscopy (SEM)}

Analisis SEM dilakukan di Laboratorium Terpadu, Fakultas MIPA Universitas Lampung. Karakterisasi SEM pada zeolit A bertujuan untuk mengetahui morfologi permukaan dan keseragaman bentuk partikel dari suatu sampel. Berikut ini adalah hasil analisis SEM yang dilakukan pada sampel variasi suhu kalsinasi $500^{\circ} \mathrm{C}, 600^{\circ} \mathrm{C}, 700^{\circ} \mathrm{C}$ dan $800^{\circ} \mathrm{C}$ yang ditunjukkan pada Gambar 3 .

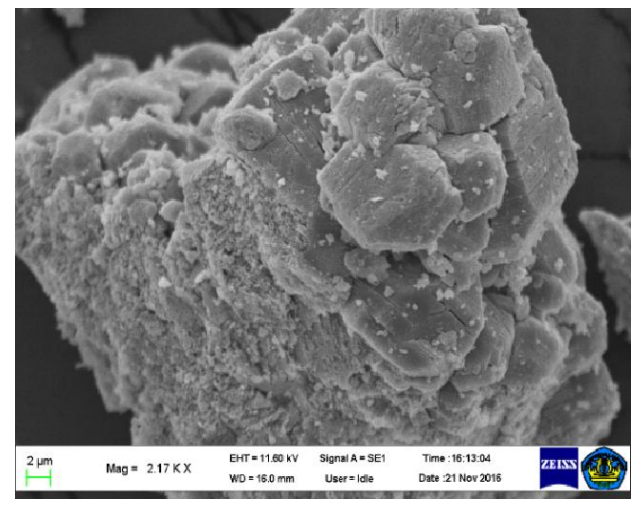

(a)

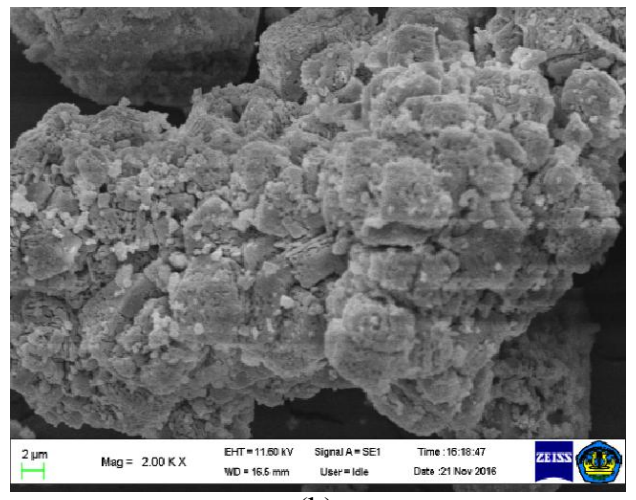

(b)

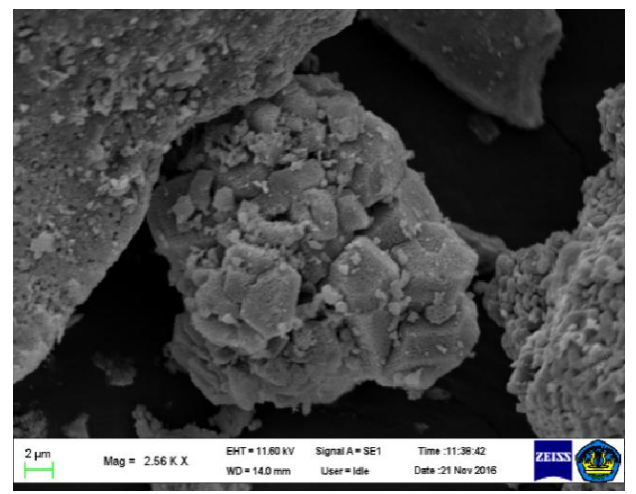

(c)

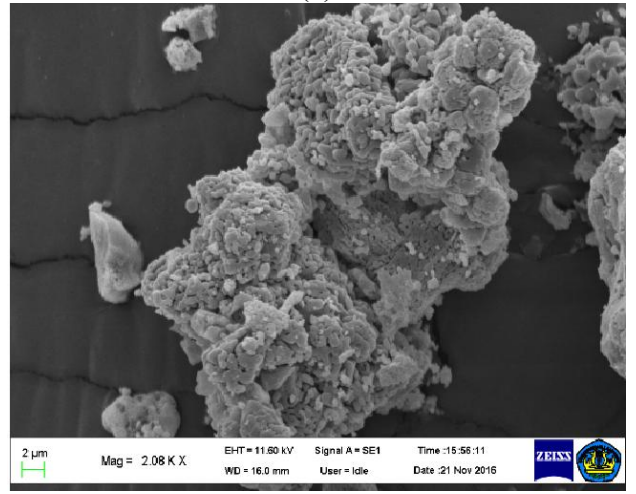

(d)

Gambar 3. Hasil SEM Zeolit A Kalsinasi (a) $500^{\circ} \mathrm{C}$, (b) $600^{\circ} \mathrm{C}$, (c) $700^{\circ} \mathrm{C}$ dan (d) $800^{\circ} \mathrm{C}$

Berdasarkan pada Gambar 3. (a) sampel dengan variasi suhu kalsinasi $500{ }^{\circ} \mathrm{C}$ terlihat bahwa bentuk partikel kubus yang paling mendominasi namun masih terdapat dalam gumpalan. Selain itu, pada sampel (a) dapat dilihat bahwa partikel yang terbentuk cukup bersih dibandingkan dengan sampel (b), (c) dan (d) karena hanya sedikit pengotor yang menempel pada partikel. Sedikitnya pengotor yang menempel pada kristal menunjukkan semakin murninya kristal tersebut [10]. Selanjutnya, pada Gambar 3. (b) (c) dan (d) terlihat 
sedikit sekali adanya morfologi partikel berbentuk kubus dan juga morfologi yang terbentuk tidak seragam yang didominasi oleh bentuk yang tidak teratur. Bentuk yang tidak teratur ini disebabkan adanya kandungan air yang tinggi [16].

Kemudian dapat dilihat masih banykanya pengotor disekitar bentuk kubus, pengotor tersebut merupakan sodalit dan cancrinite yang dihasilkan dari reaksi samping pada proses pengkristalan [10]. Pada umumnya semua variasi suhu kalsinasi terlihat bahwa bentuk partikel didominasi bentuk kubus namun memiliki bentuk yang tidak seragam dan tidak teratur. Hal ini selaras dengan hasil XRD yang membuktikan bahwa produk Zeolit A variasi suhu kalsinasi $500^{\circ} \mathrm{C}, 600^{\circ} \mathrm{C}, 700^{\circ} \mathrm{C}$ dan $800^{\circ} \mathrm{C}$ yang terbentuk memiliki persen kristalinitas yang rendah yang dapat dilihat pada Tabel 1 .

\section{Brunaur, Emmet, And Teller (BET)}

Analisis BET dilakukan di Laboratorium Elektrokimia, Teknik Kimia ITS Surabaya, dengan munggunakan Quantachrome Instruments pada temperatur 77,35 K dan Cross Section : $16.200 \AA^{2}$. Analisis ini dilakukan untuk mengetahui luas permukaan spesifik, volume dan diameter pori dari produk yang dihasilkan. Berikut ditampilkan data hasil analisis BET untuk sampel zeolit A variasi suhu kalsinasi pada Tabel 3.

Tabel 4. Hasil Analisis BET Zeolit A

\begin{tabular}{ccccc}
\hline Run & $\begin{array}{c}\text { Variasi } \\
\text { Suhu } \\
\text { kalsinasi } \\
\left({ }^{\circ} \mathrm{C}\right)\end{array}$ & $\begin{array}{c}\text { Luas } \\
\text { Permuka } \\
\text { an Total } \\
\left(\mathrm{m}^{2} / \mathrm{g}\right)\end{array}$ & $\begin{array}{c}\text { Total } \\
\text { Volume } \\
\text { Pori } \\
(\mathrm{cc} / \mathrm{g})\end{array}$ & $\begin{array}{c}\text { Diameter } \\
\text { Pori Rata } \\
- \text { Rata } \\
(\mathrm{nm})\end{array}$ \\
\hline 1 & 500 & 12,292 & 0,0109 & 3,56296 \\
2 & 600 & 3,527 & 0,0426 & 48,3675 \\
3 & 700 & 4,453 & 0,0058 & 5,21300 \\
4 & 800 & 8,249 & 0,01163 & 48,3675 \\
\hline
\end{tabular}

Berdasarkan data pada Tabel 4. dapat dilihat luas permukaan pada variasi suhu kalsinasi $800{ }^{\circ} \mathrm{C}$ sebesar $8,249 \mathrm{~m}^{2} / \mathrm{g}$ dan menurun seiring menurunnya suhu kalsinasi yaitu pada variasi suhu kalsinasi $700{ }^{\circ} \mathrm{C}$ sebesar $4,453 \mathrm{~m}^{2} / \mathrm{g}$ dan pada suhu kalsinasi $600{ }^{\circ} \mathrm{C}$ sebesar $3,527 \mathrm{~m}^{2} / \mathrm{g}$, namun luas permukaannya kembali naik pada suhu kalsinasi $500{ }^{\circ} \mathrm{C}$ yaitu sebesar $12,292 \mathrm{~m}^{2} / \mathrm{g}$. Hal ini berbanding lurus dengan nilai persen kristalinitas produk zeolit A, dimana persen kristal zeolit A juga menurun seiring dengan menurunnya suhu kalsinasi dari $800{ }^{\circ} \mathrm{C}$ ke suhu kalsinasi $700{ }^{\circ} \mathrm{C}$ dan $600{ }^{\circ} \mathrm{C}$, kemudian persen kristal zeolit A naik kembali pada suhu $500{ }^{\circ} \mathrm{C}$. Maka dapat disimpulkan bahwa luas permukaan terbesar didapatkan pada produk zeolit
A dengan persen kristal terbesar pula. Semakin besar luas permukaan zeolit maka akan semakin besar kemampuannya untuk berinteraksi dan berikatan dengan molekul - molekul air dalam etanol, maka dalam hal ini zeolit dengan variasi kalsinasi $500{ }^{\circ} \mathrm{C}$ yang paling baik. Dapat dilihat pada Tabel 4. Diameter pori-pori nya berkisar antara 3 sampai $48 \mathrm{~nm}$, hal tersebut menunjukkan zeolit A yang terbentuk merupakan zeolit A yang memiliki kisaran diameter mesopori $(2-50 \mathrm{~nm})$ atau (20 ̊́-500 Á) [17].

Karakteristik padatan berpori meso juga dapat dilihat dari data grafik distribusi ukuran pori dengan menggunakan metode BJH (Barret, Joiner, Halenda) adsorpsi dan desorpsi. Berikut ini adalah grafik distribusi ukuran pori yang didapat dari hubungan perubahan volume pori per gram sampel $(\mathrm{cc} / \mathrm{nm} / \mathrm{g}$ ) terhadap diameter pori (nm) adsoprsi dan desorpsi yang didapat dari data distribusi ukuran pori sampel zeolit A untuk variasi suhu kalsinasi $500{ }^{\circ} \mathrm{C}, 600{ }^{\circ} \mathrm{C}, 700{ }^{\circ} \mathrm{C}$ dan $800{ }^{\circ} \mathrm{C}$, disajikan dalam Gambar 4.

Berdasarkan Gambar 4 (a). dapat dilihat bahwa semua sampel variasi suhu kalsinasi $500{ }^{\circ} \mathrm{C}$, $600{ }^{\circ} \mathrm{C}, 700{ }^{\circ} \mathrm{C}$ dan $800{ }^{\circ} \mathrm{C}$ menunjukkan pori berukuran mesopori yang teramati pada grafik distribusi ukuran pori adsorpsi dengan terus menunjukkan kenaikan pada diameter pori sekitar 3-30 nm. Pada variasi suhu kalsinasi $500{ }^{\circ} \mathrm{C}$ terjadi kenaikan perubahan volume pori per gram sampel pada diameter pori 3 sampi $16 \mathrm{~nm}$. Kemudian pada variasi suhu kalsinasi $600{ }^{\circ} \mathrm{C}$ terjadi kenaikan perubahan volume pori per gram sampel pada diameter pori $3-30 \mathrm{~nm}$, sedangkan pada variasi suhu kalsinasi $700{ }^{\circ} \mathrm{C}$ terjadi kenaikan perubahan volume pori per gram sampel pada diameter pori 3 sampai $17 \mathrm{~nm}$ dan 7 sampai $31 \mathrm{~nm}$ pada variasi suhu $800{ }^{\circ} \mathrm{C}$. Semakin besar jarak diameter pori yang dihasilkan maka hal ini menunjukkan semakin selektifnya zeolit A dalam melakukan adsorpsi terhadap molekul-molekul mana yang akan masuk ke dalam rongga zeolit dan mana yang akan ditolak [3]. 

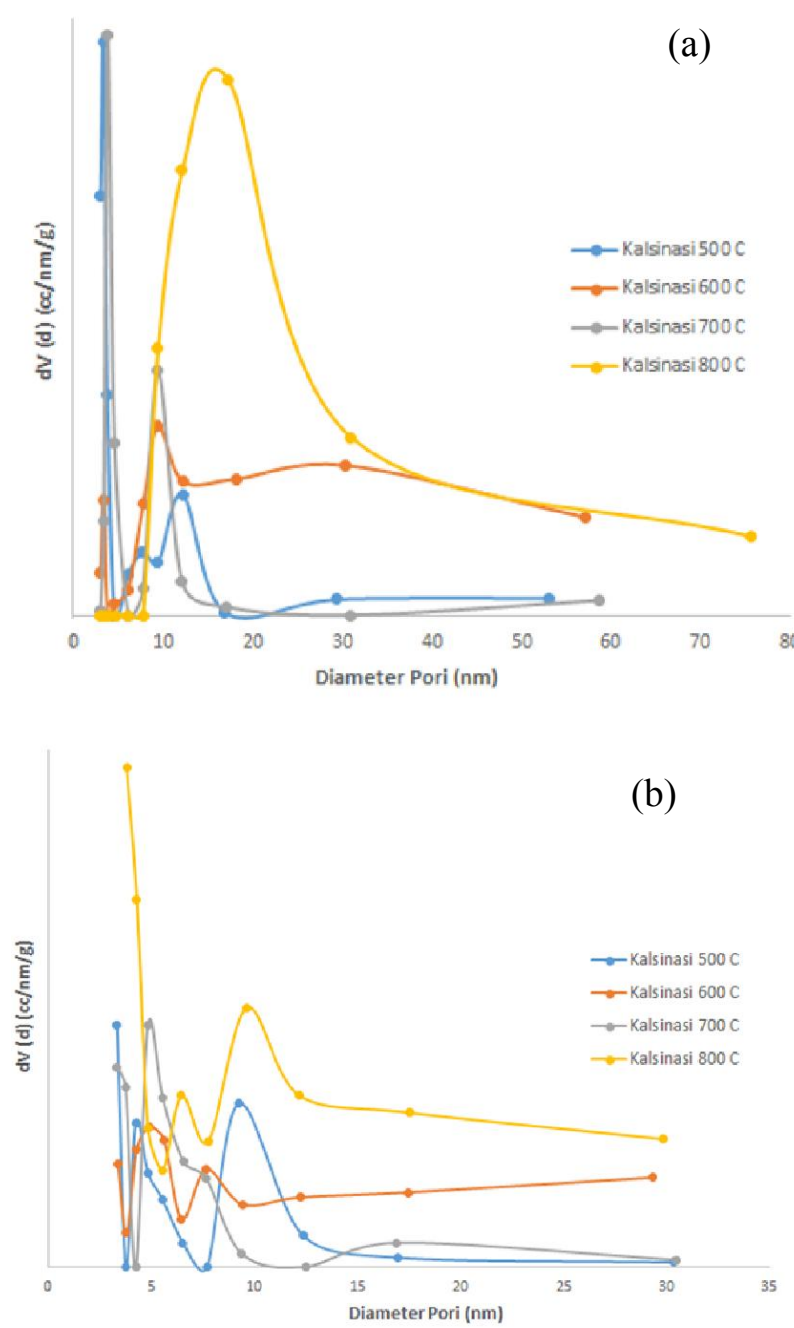

Gambar 4. Grafik Distribusi Ukuran Pori Zeolit A

(a) Adsorpsi dan (b) Desorpsi

Berdasarkan Gambar 4 (b). dapat dilihat bahwa semua sampel variasi suhu kalsinasi $500{ }^{\circ} \mathrm{C}$, $600{ }^{\circ} \mathrm{C}, 700{ }^{\circ} \mathrm{C}$ dan $800{ }^{\circ} \mathrm{C}$ menunjukkan pori berukuran mesopori yang teramati pada grafik distribusi ukuran pori desorpsi dengan terus menunjukkan kenaikan pada diameter pori sekitar 3-30 nm. Pada variasi suhu kalsinasi $500{ }^{\circ} \mathrm{C}$ terjadi kenaikan perubahan volume pori per gram sampel pada diameter pori 3 sampi $17 \mathrm{~nm}$. Kemudian pada variasi suhu kalsinasi $600{ }^{\circ} \mathrm{C}$ terjadi kenaikan perubahan volume pori per gram sampel pada diameter pori $3-30 \mathrm{~nm}$, sedangkan pada variasi suhu kalsinasi $700{ }^{\circ} \mathrm{C}$ terjadi kenaikan perubahan volume pori per gram sampel pada diameter pori 3 sampai $30 \mathrm{~nm}$ dan 4 sampi $17 \mathrm{~nm}$ pada variasi suhu $800{ }^{\circ} \mathrm{C}$. Semakin besar jarak diameter pori yang dihasilkan maka hal ini menunjukkan semakin tidak selektifnya zeolit A dalam meloloskan zat zat yang keluar dari pori [3].
Proses analisa material pori meso maupun mikro dapat diketahui melalui metode grafik t-plot berdasarkan nilai perbandingan antara ketebalan dinding pori (nm) dengan perubahan volume $\mathrm{N}_{2}$ per gram sampel (cc/g) yang dapat dilihat pada Gambar 5.

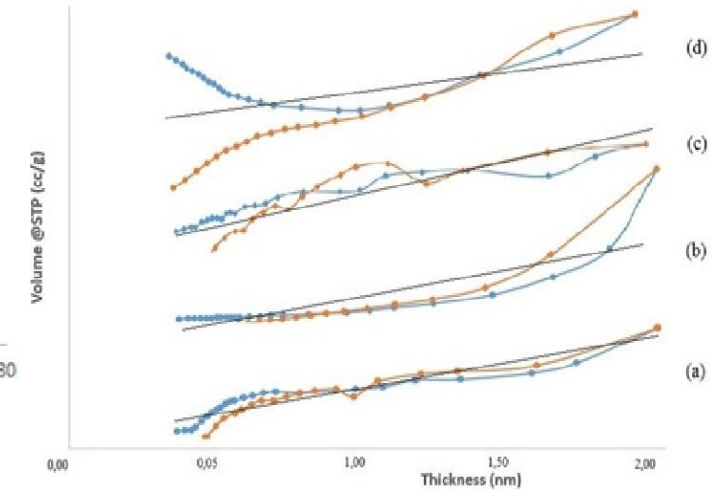

Gambar 5. Grafik T-Plot Zeolit A variasi suhu kalsinasi (a) $500{ }^{\circ} \mathrm{C}$, (b) $600{ }^{\circ} \mathrm{C}$, (c) $700{ }^{\circ} \mathrm{C}$ dan $(\mathrm{d}) 800^{\circ} \mathrm{C}$.

Pada gambar 5. grafik t-plot terlihat bahwa semua sampel memiliki pola yang berbeda namun memiliki garis linear vertikal yang sama. Garis linear horizontal pada $t$-plot menunjukkan adanya mikropori, sedangkan garis vertikal menunjukkan adanya mesopori [18]. Dari grafik diatas dapat disimpulkan bahwa semua sampel memiliki pori yang seragam yang berukuran mesopori yang ditandai dengan garis vertikal pada tiap sampel.

\section{Uji Adsorpsi Campuran Etanol-Air}

Pada penelitian ini juga dilakukan uji adsorpsi terhadap air dalam etanol dengan variasi suhu kalsinasi $500{ }^{\circ} \mathrm{C}, 600{ }^{\circ} \mathrm{C}, 700{ }^{\circ} \mathrm{C}$ dan $800{ }^{\circ} \mathrm{C}$ pada saat perlakuan awal pembuatan zeolit A. salah satu komponen yang terdapat dalam etanol adalah air yang merupakan fasa teradsorpsi. Air bersifat polar dan sangat mudah teradsorpsi pada permukaan zeolit sehingga air mengisi ronggarongga di dalam kristal zeolit. Begitu pula dengan zeolit A mengandung saluran terbuka yang besar sehingga memudahkan air untuk bergerak keluar masuk struktur kristal. Berikut merupakan hasil adsorpsi variasi suhu kalsinasi sintesis zeolit A, dapat dilihat pada Gambar 6. 


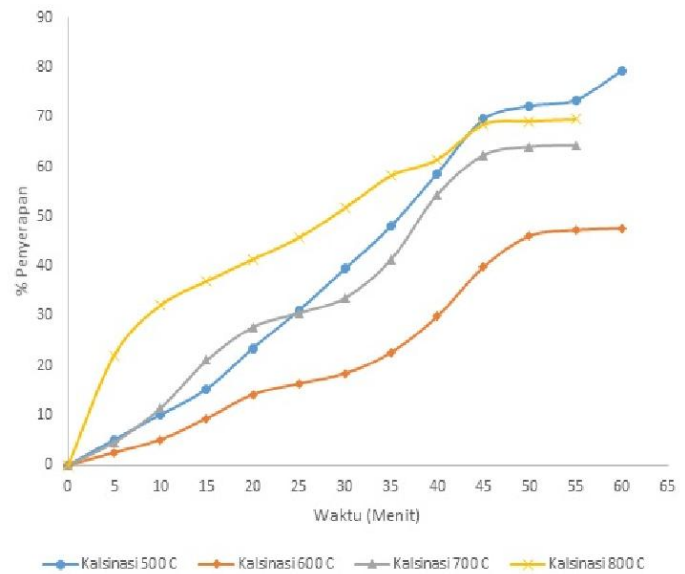

Gambar 6. Kurva Adsorpsi etanol-air pada zeolit A variasi suhu kalsinasi dengan kadar etanol awal 96\%

Berdasarkan Gambar 6. dapat diketahui bahwa semakin lama waktu penyerapan, maka semakin banyak kadar air yang terserap. Banyaknya kadar air yang dapat terserap dipengaruhi oleh volume pori yang mana bila volume pori sudah terisi penuh dengan molekul-molekul air maka akan menyebabkan keadaan jenuh dari adsorben yang ditandai dengan konstannya kurva pada gambar 6 .

Selanjutnya untuk mengetahui nilai persen penyerapan air dari etanol dapat dilihat pada Tabel 4. yang merupakan hasil adsorpsi pada setiap run pada masing-masing variasi suhu kalsinasi dengan kadar etanol awal $96 \%$ dan massa zeolit A yang digunakan untuk mengadsorp air dari campuran etanol air sebanyak tiga gram dengan waktu pengambilan data adsorpsi yang digunakan setiap lima menit.

Tabel 4. Kadar Air Terserap

\begin{tabular}{ccccc}
\hline $\begin{array}{c}\text { Kalsinasi } \\
\text { (C) }\end{array}$ & $\begin{array}{c}\text { Waktu } \\
\text { (menit) }\end{array}$ & $\begin{array}{c}\text { (\%) Kadar } \\
\text { Etanol } \\
\text { Akhir }\end{array}$ & $\begin{array}{c}\text { Kadar } \\
\text { air } \\
\text { dalam } \\
\text { Etanol }\end{array}$ & $\begin{array}{c}\text { Penyisihan } \\
\text { Air }\end{array}$ \\
\hline 500 & 60 & 99,202 & 0,798 & 79,367 \\
600 & 60 & 97,973 & 2,026 & 47,618 \\
700 & 55 & 98,619 & 1,380 & 64,298 \\
800 & 55 & 98,821 & 1,178 & 69,522 \\
\hline
\end{tabular}

Dari Tabel 4. dapat dilihat persen penyerapan air tertinggi pada zeolit A variasi kalsinasi $500{ }^{\circ} \mathrm{C}$ sebanyak $79,367 \%$ selama 60 menit dan didapatkan persen kadar etanol sebesar $99,202 \%$. Sedangkan penyerapan air terendah yaitu pada zeolit A variai kalsinasi $600{ }^{\circ} \mathrm{C}$ yaitu sebanyak $47,618 \%$ selama 60 menit dan didapatkan persen kadar etanol sebesar 97,973 \%. Banyaknya air yang dapat diserap berkaitan dengan luas permukaan zeolit A yang dihasilkan. Hasil uji adsorpsi ini mendukung hasil analisi BET, pada Tabel 4. didapatkan luas permukaan terbesar yaitu pada variasi suhu kalsinasi $500{ }^{\circ} \mathrm{C}$ sedangkan luas permukaan terkecil yaitu pada variasi suhu kalsinasi $600{ }^{\circ} \mathrm{C}$. Luas permukaan zeolit sangat berpengaruh terhadap kemampuan zeolit sebagai adsorben. Jika luas permukaan zeolit semakin besar, maka kemampuan zeolit untuk menyerap senyawasenyawa lain akan semakin baik hal ini disebabkan oleh permukaan interaksi yang lebih luas [3].

\section{KESIMPULAN}

Berdasarkan hasil analisis XRD untuk semua variasi suhu kalsinasi $500^{\circ} \mathrm{C}, 600^{\circ} \mathrm{C}, 700^{\circ} \mathrm{C}$ dan $800^{\circ} \mathrm{C}$ telah terbentuk produk utama Zeolit $\mathrm{A}$ dengan produk samping berupa Corondum, Anorthite, Mullite, sodalit dan cancrinite.

Berdasarkan perhitungan persen kristalinitas Zeolit A dengan metode estimation of crystallinity, persen kristalinitas tertinggi pada variasi suhu kalsinasi $500^{\circ} \mathrm{C}$ yaitu sebesar $34,79 \%$. Hal ini menunjukkan semakin tinggi suhu kalsinasi coal bottom ash, maka kristalinitas zeolit A sintesis cenderung semakin kecil.

Berdasarkan hasil analisis FTIR, seluruh sampel pada variasi suhu kalsinasi $500^{\circ} \mathrm{C}, 600^{\circ} \mathrm{C}$, $700^{\circ} \mathrm{C}$ dan $800^{\circ} \mathrm{C}$ telah terbentuk produk Zeolit A yang ditandai dengan adanya karakteristik Zeolit A pada bilangan gelombang $950-1250 \mathrm{~cm}^{-1}, 650-$ $750 \mathrm{~cm}^{-1}, \quad 500-650 \mathrm{~cm}^{-1}, \quad 420-500 \mathrm{~cm}^{-1}$ dan $300-$ $400 \mathrm{~cm}^{-1}$.

Berdasarkan hasil analisis SEM, Pada umumnya semua variasi suhu kalsinasi terlihat bahwa bentuk partikel didominasi bentuk kubus namun memiliki bentuk yang tidak seragam dan tidak teratur dan juga masih banyaknya pengotor disekitar bentuk kubus yang merupakan sodalit dan cancrinite yang dihasilkan dari reaksi samping pada proses sintesis.

Berdasarkan hasil analisis dengan metode BET pada sampel Zeolit A variasi suhu kalsinasi $500^{\circ} \mathrm{C}, 600^{\circ} \mathrm{C}, 700^{\circ} \mathrm{C}$ dan $800^{\circ} \mathrm{C}$ menunjukkan bahwa semakin rendah suhu kalsinasi maka cenderung semakin besar luas permukaan Zeolit A. Luas permukaan terbesar diperoleh pada variasi suhu kalsinasi $500{ }^{\circ} \mathrm{C}$ yaitu sebesar $12,292 \mathrm{~m}^{2} / \mathrm{g}$.

Dengan menggunakan metode BJH adsorpsi dan desorpsi diperoleh material mesopori pada semua sampel variasi suhu kalsinasi dengan ukuran 3-30 nm. Selain itu, dengan metode t-plot diperoleh ukuran pori yang seragam yang berukuran mesopori yang ditandai dengan garis vertikal pada tiap sampel.

Berdasarkan uji adsorpsi etanol-air yang telah dilakukan diketahui adsorpsi terbaik 
dilakukan oleh produk zeolit dengan variasi suhu kalsinasi $500^{\circ} \mathrm{C}$ dengan melakukan penyerapan air sebanyak 79,367\%.

\section{DAFTAR PUSTAKA}

[1] Clark J. 2007. Pembuatan Alkohol dalam Skala Produksi. http://www.chem-is-try.org

[2] [Nurdyastuti I. 2005. Teknologi Proses Produksi Bio-Ethanol. Prospek pengembangan biofuel sebagai substitusi bahan bakar minyak.

[3] Khaidir. 2011. Modifikasi Zeolit Alam Sebagai Material Molecular Sieve dan Aplikasinya pada Proses Dehidrasi Bioetanol. Tesis. Institut Pertanian Bogor.

[4] Tanaka, H. 2002. Formation of Na-A and Na$\mathrm{X}$ Zeolite from Wate Solution in Conversion of Coal Bottom Ash to Zeolites. Material Research Buletin, Vol.37,Hal. 1873-1884.

[5] Mortimer M, Taylor P. 2002. Chemical kinetics and mechanism. Cambridge: RSC.

[6] [Hui K.S, Chao C.Y.H. 2005. Effects Of StepChange Of Synthesis Temperature On Synthesis Of Zeolite 4A From Coal Fly Ash. Hong Kong : Elsevier science.

[7] M. Mirfendereski, T. Mohammadi. 2016. Effects of Synthesis Parameters on the Characteristics of Naa Type ZeoliteNanoparticles. Tehran. Shahid Beheshti University.

[8] Joao Rocha and Jacek Klinowski, 1991, Synthesis of Zeolite Na-A from Metakaolinite Revisited, University of Cambridge, UK.

[9] Barrer, R., Villiger., Z. Kristallogr., Kristallgeom., Kristallphys., Kristallchem., $142,82,(1975)$

[10] Carlos Alberto, Craig Denver and Oscar Mauricio. 2010. Synthesis of zeolite LTA from thermally treated kaolinite. Colombia. Universidad de Pamplona.

[11] [11] Rayalu, S.S., Udhoji, J.S., S.U. Meshram., R.R. Naidu and S. Devotta, 2005. Estimation of crystallinity in flyash- based zeolite-A using XRD and IR Spectroscopy. India. Current Science, Vol.89, No.12.

[12] Janjira W. 2002. Synthesis And Kinetic Study Of Zeolite Na-A From Thai Kaolin. Thesis.Suranaree : Suranaree University Of Technology.

[13] Hamdan, H., 1992, "Introduction to Zeolite Syn-thesis, Characterization and Modification", 1st Edition, Universiti Teknologi Malaysia, Kualalumpur.
[14] Sulardjaka dan Deni Fajar Fitriyana. 2016. Pengaruh Konsentrasi $\mathrm{NaOH}$ dan Waktu Penahanan Terhadap Karakteristik Zeolit yang disintesis dari Limbah Geothermal. Reaktor, Vol 1 No. 1. Universitas Diponegoro.

[15] Xu, R., Pang, W., Yu, J., Huo, Q., and ChenJ., 2007. Chemistry of Zeolites and Related Porous Material Synthesis and Structure, Jhon Wiley \& Sons (Asia)Pte Ltd, Singapore.

[16] Pan, Feng., Lu, Xuchen., Yun Wang., Shiwei Chen., Tizhuang Wang dan Yan Yan. 2014. Microporous and Mesoporous Material. Journal Elsevier. 184 : 134-140.

[17] Gregg SJ \& Sing KSW. 1982. Adsorption, Surface Area and Porosity.2nd Edition, London: Academic Press.

[18] [Storck S, Bretinger H \& Maier WF. 1998. Characterization of Micro- and Mesoporous Solids by Physisorption Methods and Pore-size Analysis. Applied Catalysis A: Genera.174:137- 146 .

[19] Guatieri, A., Artioli, G. Hanson, J., and Norby, P. (1997). Kinetic of formation of zeolite Na-A [LTA] from kaolinite. J. Phys. Chem. Mineral. 24: 191-199 